\title{
Management of Innovations in the Supply Chains of Russian Oil and Oil Products Taking Into Account Regional Structure
}

\author{
Beilin Igor Leonidovich \\ ${ }^{1}$ Tatar Scientific Research Institute of Agriculture, FRC Kazan Scientific Center, \\ Russian Academy of Sciences, Kazan Federal University, Russia.
}

\begin{abstract}
The article analyzes relevant factual information characterizing the state and use of the mineral resource base of the Russian Federation, as well as analytical materials that illuminate the state of affairs in the mineral resource complex of the country and the world. The relevant data of industry and state statistics, program, regulatory, methodological and reporting documents of the Ministry of Natural Resources of Russia, Rosnedr, territorial bodies and subordinate organizations of the Agency, data of mining companies and processing enterprises are presented. Maximum reliability and completeness of information, comparability of indicators, unification of the conceptual and terminological base and forms of presentation of actual data are provided. Based on the analysis of the data presented and the simplex optimization method, author's approaches to innovation management in the supply chains of Russian oil and oil products were proposed taking into account the regional structure. They are presented in the format of contour maps, which make it possible to determine both the optimal ratios of influencing factors on the studied indicator and the ratios of these factors for any possible outcomes of their mutual influence. The presented method makes a new contribution to the methodology for managing the supply chains of oil and oil products and creates additional opportunities for managing innovation in the export of oil and gas regions.
\end{abstract}

Keywords: supply chain management, economics, econometrics, innovation management, regional economy, oil and oil products

\section{INTRODUCTION}

The Russian mineral and raw material base is the foundation of the Russian economy and is a combination of differentranking subsoil fund objects (deposits, ore occurrences, etc.), characterized by proven and estimated reserves and proven predicted mineral resources. Russia has a large raw material base for liquid hydrocarbons, providing the country with sixth place among the countries that hold reserves, twelfth place in production, thirteenth in export and seventh in oil refining capacities (Table 1).
Table 1. Russia's share in world reserves, production and export of crude oil

\begin{tabular}{|c|c|c|}
\hline Index & $\%$ & $\begin{array}{c}\text { Place in } \\
\text { the world }\end{array}$ \\
\hline Stocks & 6 & 6 \\
\hline Mining & 12 & 3 \\
\hline Crude oil export & 13 & 2 \\
\hline $\begin{array}{c}\text { Oil refineries } \\
\text { power }\end{array}$ & 7 & 3 \\
\hline
\end{tabular}

According to the State balance of mineral reserves of the Russian Federation, technologically recoverable oil reserves of Russia as of 01.01.2019 amounted to 29.8 billion tons, condensate -4.1 billion tons. The transnational oil and gas company British Petroleum (BP) estimates the Russian proved reserves (proved reserves) of liquid hydrocarbons of 14.6 billion tons ( $6 \%$ of the world). In terms of the daily and annual oil production rates (11.4 million barrels per day or 554.6 million tons in 2018), Russia confidently ranks third in the world, second only to the United States and Saudi Arabia. The depletion of oil reserves is $56.2 \%$, while about $60 \%$ of current reserves are difficult to extract (high viscosity oils, low permeability and low thickness reservoirs, sub-gas zones, etc.). The potential for building up the oil resource base is high; its prepared and forecasted resources almost double the amount of recoverable reserves. Crude oil production in Russia for the period from 2009 to 2018 increased by $9 \%$ and reached 520.1 million tons. Crude oil exports, which consistently account for about half of the production volume, increased by $5.3 \%$ over the same period. About a third of oil products produced by domestic enterprises are also sent to foreign consumers. In 2012-2015 the volumes of these deliveries were actively growing, but in the next two years there was a decrease; in 2018, supplies began to grow again (Fig. 1). 


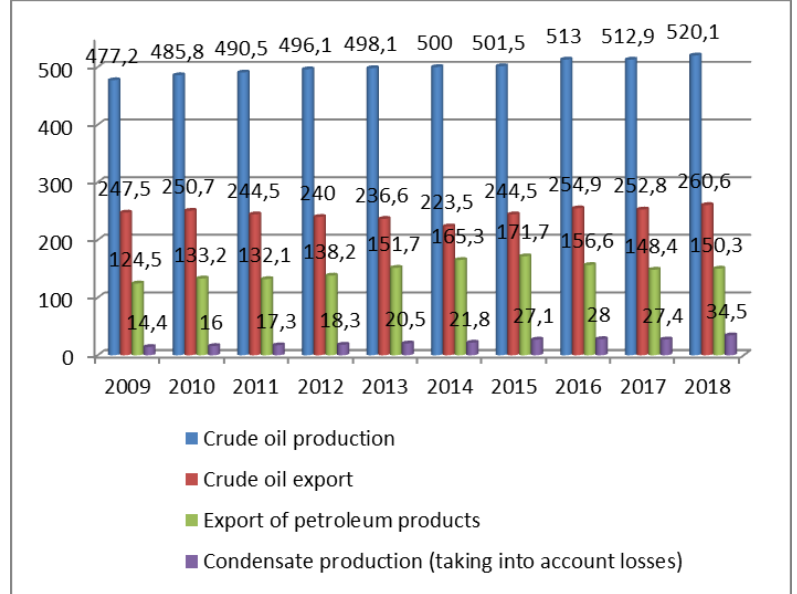

Fig. 1. Dynamics of crude oil and condensate production, export of crude oil and oil products from Russia in 20092018, mln tons

\section{METHODOLOGY}

The main source of information on the quantity, quality and degree of study of the reserves of each type of minerals, their location, the degree of industrial development, production, production losses and other changes, as well as the technical and economic indicators of enterprises for mining and processing of mineral raw materials are the issues of state mineral balance. They are published by the Federal State Budget Institution "Russian Federal Geological Fund" (FSBI "Rosgeolfond"). In accordance with the schedule for the publication of issues of the state balance of mineral reserves as of $01 / 01 / 2019$, the information is preliminary and is given for the release of summary data on the status of reserves and mining in the Russian Federation. Information on foreign trade operations of the Russian Federation is given according to the Federal Customs Service. The main indicators of the state of the mineral resource complex of the countries of the world are given on the basis of the results of work obtained as part of the fulfillment of the state task by the Federal State Budgetary Institution "All-Russian Scientific Research Institute of Mineral Raw Materials named after N.M. Fedorovsky "(FSBI "VIMS").

When comparing the raw material bases of different countries of the world, mineral resources are understood as the estimated amount of mineral raw materials contained in a specific natural object. Reserves are understood as the part of resources that, taking into account the current market, is profitable for mining by its technological, mining, geological, hydrogeological, economic and geographical conditions. For the correct comparison of the raw material bases of the countries of the world, the basis is taken to estimate the reserves of specific objects, carried out in accordance with the international reporting standard on the results of exploration, mineral resources and reserves of TPI (CRIRSCO template). For the overwhelming majority of countries, the reserve estimate is the sum of the reserves of the "Proved + Probable Reserves" categories of exploited, prepared for exploitation and explored deposits available in the territory of a given country. Given the objective impossibility of estimating the total reserves of deposits (China, Brazil, India, etc.), the statistics used were data from official statistical agencies and / or sites of geological services of these countries.

In this case, mineral reserves are given in the categories used in the information sources that do not coincide with the categories of reporting codes of the "CRIRSCO family" countries, but representing their counterpart: in Brazil, the Reserva Lavravel category, in China the Ensured Reserves category, in India - Reserves. For hydrocarbons, coal and uranium, materials from international and private specialized consulting agencies that monitor and produce statistical materials on one or more types of mineral raw materials were used.

\section{RESULTS}

The main direction of external deliveries of Russian raw materials is traditionally European countries - more than two thirds of domestic exports go here. The main buyers in the region remain the Netherlands (16-19\%) and Germany (89\%); also significant role of Poland, Italy and Finland. The European direction also includes supplies to Belarus, which began in 2012, but their share in the aggregate indicator is reduced: in 2017-2018. It amounted to $7 \%$ versus $9 \%$ in 2015 , while the physical volumes remained unchanged during this period.

An important export destination, the role of which is growing steadily, has become the countries of the Asia-Pacific region, primarily the People's Republic of China; this is facilitated by the possibility of increasing the loading of crude oil from the East Siberia-Pacific Ocean oil pipeline. Over ten years, supplies to China grew 5.5 times: from 12 million tons in 2009 (about 5\% of Russian exports) to 67 million tons in 2018 $(26 \%)$. The Republic of Korea also acts as a major consumer of Russian oil in the region, where more than $5 \%$ of exports go. Due to the fact that the vast majority of oil refineries in the country are included in the structure of vertically integrated companies, they are provided with their own raw materials [16]. In this regard, the import of crude oil into Russia is insignificant; he comes from Kazakhstan, mainly to the Orenburg region. In general, since 2009, the amount of oil products exported from Russia has increased by $24 \%$, from 124.5 million tons to 150.3 million tons in 2018 (Fig. 2). The overwhelming (about 94\%) sent to non-CIS countries; the share of the CIS countries in different years was 3-12\% (5-17 million tons). The key export destination to Europe is the Netherlands, which supplies $17-22 \%$ of Russia's oil output. There is an increase in deliveries to Malta and Turkey - their share in exports grew to $6-7 \%$ by 2018 . About $3-4 \%$ goes to Germany and Belgium, in recent years there has been an increase in deliveries to Denmark and the UK against the background of a significant reduction in supplies to Italy and Latvia. Over $5 \%$ of exports go to the USA. Among the countries of the Asian region, the main consumers of oil products are China, the Republic of Korea and Singapore (over 3-4\% of exports in 2018).

About a third of oil products are supplied to the domestic market, fully meeting the demand from domestic consumers 
for widely sought-after products - gasoline (35.2 million tons in 2017), diesel (33.1 million tons), aviation kerosene (9.7 million tons) and heating oil (10.3 million tons). Imported mainly special fuels and in small quantities [7-11]. Thus, the Russian raw material base of liquid hydrocarbons, due to its significant scale and high quality characteristics of the raw materials contained in the bowels, allows the country to become one of the world leaders in the supply of both crude oil and petroleum products. Recoverable oil reserves are estimated in more than 50 countries of the world and are estimated at 244 billion tons, the volume of world crude oil production in 2018 amounted to $4,474.3$ million tons (Tables $2,3)$.

Table 2. Reserves (with condensate and dissolved gas) in the leading countries of the world

\begin{tabular}{|c|c|c|}
\hline \multirow{2}{*}{ Country } & \multicolumn{2}{|c|}{ Proved reserves } \\
\cline { 2 - 3 } & $\begin{array}{c}\text { Billion } \\
\text { barrels }\end{array}$ & $\begin{array}{c}\text { Share in world } \\
\text { stocks, \% }\end{array}$ \\
\hline USA & 61,2 & 4 \\
\hline Saudi Arabia & 297,7 & 17 \\
\hline Russia & 106,2 & 6 \\
\hline Canada & 167,8 & 10 \\
\hline Iraq & 147,2 & 9 \\
\hline Iran & 155,6 & 9 \\
\hline Venezuela & 303,3 & 17 \\
\hline Other & 490,7 & 28 \\
\hline World & 244,1 & 100 \\
\hline
\end{tabular}

According to BP Statistical Review of World Energy

Table 3. Oil production (with condensate and dissolved gas) in the leading countries of the world

\begin{tabular}{|c|c|c|}
\hline \multirow{2}{*}{ Country } & \multicolumn{2}{|c|}{ Oil production in 2018 } \\
\cline { 2 - 3 } & $\begin{array}{c}\text { Million } \\
\text { barrels /day }\end{array}$ & $\begin{array}{c}\text { Share in the } \\
\text { world } \\
\text { production, } \%\end{array}$ \\
\hline USA & 15,3 & 15 \\
\hline $\begin{array}{c}\text { Saudi } \\
\text { Arabia }\end{array}$ & 12,3 & 13 \\
\hline Russia & 11,4 & 12 \\
\hline Canada & 5,2 & 6 \\
\hline Iraq & 4,6 & 5 \\
\hline Iran & 4,7 & 5 \\
\hline Venezuela & 1,5 & 2 \\
\hline Other & 39,7 & 42 \\
\hline World & 94,7 & 100 \\
\hline
\end{tabular}

According to the official state statistics of Russia
Since 2017, the United States has become the main supplier of crude oil to the market, ahead of Saudi Arabia; Thanks to the successful implementation of shale reservoir development technologies, since 2014 the country annually provides over $12 \%$ of world production. The shale Perm basin located in the states of Texas and New Mexico became the center of production in the USA. The bulk of traditional oil reserves are concentrated on the Gulf of Mexico. Saudi Arabia in 2018 provided $13 \%$ of world oil production, increasing it by $3 \%$ after a reduction in 2017 under the OPEC + agreement. The country supplies the world market with high-quality raw materials - light low-sulfur oil. The deposits are distinguished by favorable mining and mining conditions and are characterized by low production costs.

The main countries supplying crude oil, each of which accounts for at least 5\% of global production, from 2017 include Canada, Iran and Iraq, which are gradually increasing production in accordance with global demand growth trends [12-19]. In Venezuela, against the backdrop of an unstable economic and political situation, the downward trend in oil production continued: in 2018 , it decreased by another $28 \%$. The country has the largest oil reserves in the world, but most of it is represented by heavy and extra heavy oil contained in the tar sands of the Orinoco oil and gas basin.

In recent years, in the world, compensation for liquid hydrocarbon reserves paid off as a result of production is mainly carried out at the expense of non-traditional sources [20-24]. Traditional sources compensate only $15-20 \%$ of the repayment, which indicates a high exploration of the world's main oil and gas basins and a qualitative deterioration in the state of traditional reserves in the world. In oil and gas production, shale (shale-like) strata are becoming increasingly important, primarily due to their development in the United States.

Due to the uniqueness of the oil of each particular field in terms of chemical and fractional composition and physical properties that affect the process of its processing, "marker" or "reference" types of oil were introduced to simplify international trade, which are characterized by certain boundary values of the main indicators. Specific varieties are associated with specific production regions (Tables 4, 5).

Table 4. Areas of production of marker grades of oil

\begin{tabular}{|c|c|}
\hline Oil brands & Production area \\
\hline Frent & $\begin{array}{c}\text { Deposits of the North seas, } \\
\text { Offshore Scotland and Norway }\end{array}$ \\
\hline $\begin{array}{c}\text { West Texas } \\
\text { Intermediate } \\
\text { (WTI) }\end{array}$ & State of Texas (USA) \\
\hline $\begin{array}{c}\text { Dubai Crude } \\
\text { Emirate of Dubai }\end{array}$ \\
\hline \multicolumn{2}{|c|}{ Russian varieties } \\
\hline
\end{tabular}


International Journal of Engineering Research and Technology. ISSN 0974-3154, Volume 13, Number 11 (2020), pp. 3479-3484

(C) International Research Publication House. https://dx.doi.org/10.37624/IJERT/13.11.2020.3479-3484

\begin{tabular}{|c|c|}
\hline Urals & $\begin{array}{c}\text { Republic of Bashkortostan } \\
\text { and Tatarstan, Khanty-Mansi } \\
\text { Autonomous Okrug-Ugra }\end{array}$ \\
\hline ESPO & Eastern Siberia \\
\hline Sokol & Sakhalin-1 \\
\hline Siberian Light & $\begin{array}{c}\text { Khanty-Mansi } \\
\text { Autonomous Okrug-Ugra }\end{array}$ \\
\hline Vityaz & Sakhalin-2 \\
\hline $\begin{array}{c}\text { Arctic Oil } \\
\text { (ARCO) }\end{array}$ & Prirazlomnoe \\
\hline
\end{tabular}

Table 5. Main characteristics of marker grades of oil in density and sulfur content

\begin{tabular}{|c|c|c|c|}
\hline Oil brands & $\begin{array}{c}\text { Density,kg } \\
\text { / cu m }\end{array}$ & $\begin{array}{c}\text { Density } \\
\text { API, } \\
\text { hail }\end{array}$ & $\begin{array}{c}\text { Sulphurous, } \\
\%\end{array}$ \\
\hline \multicolumn{4}{|c|}{ Foreign varieties } \\
\hline Brent & $825-828$ & $\begin{array}{c}39,4- \\
40\end{array}$ & 0,37 \\
\hline $\begin{array}{c}\text { West Texas } \\
\text { Intermediate } \\
\text { (WTI) }\end{array}$ & 827 & 39,6 & 0,24 \\
\hline $\begin{array}{c}\text { Dubai } \\
\text { Crude }\end{array}$ & 870 & 31 & 2 \\
\hline \multicolumn{2}{|c|}{ Russian varieties } \\
\hline Urals & $860-871$ & $31-32$ & $1,2-1,3$ \\
\hline ESPO & $851-855$ & 34,8 & 0,62 \\
\hline Sokol & $835-837$ & 36,7 & 0,23 \\
\hline Aiberian & $845-850$ & 36,5 & 0,57 \\
\hline Vityaz & $820-823$ & 41 & 0,18 \\
\hline $\begin{array}{c}\text { Arctic Oil } \\
\text { ARCO) }\end{array}$ & 906 & 24 & 2,3 \\
\hline
\end{tabular}

\section{DISCUSSION AND CONCLUSION}

There are several major marker grades of oil, of which the most significant on the market are Brent, WTI and Dubai Crude, the prices of which are set during trading on international exchanges. For other varieties, the cost is calculated based on differences with the reference [25-28]. As a reference for European and Asian oil, Brent crude oil is used, which is produced on the shelf of the North Sea and is a mixture of varieties produced at four fields in the region:

\section{Brent, Forties, Oseberg, Ekofisk.}

It is characterized by a predominance of light fractions and sulfur content. Similar parameters are possessed by the Texas brand West Texas Intermediate (WTI) - the benchmark for the varieties of oil produced in the United States and other countries of the Western Hemisphere. For a comparative characterization of varieties coming from the Middle East and Asia-Pacific regions, the parameters of the Dubai Crude brand produced in the emirate of Dubai (UAE) are used - it is somewhat heavier than Brent and WTI and noticeably sulfurous.

The main grade of Russian oil is Urals - it accounts for about $83 \%$ of Russian exports. It is distinguished by a fairly high density, comparable to the Dubai brand, and an average sulfur level. About $12 \%$ of supplies come from the relatively low sulfur and lighter ESPO. Sokol, Siberian Light, Vityaz, Arctic Oil (ARCO) are also in demand on the world market. The downward trend in oil prices, mainly due to the excess supply of oil on the market, continued during 2013-2020 (fig. 2).

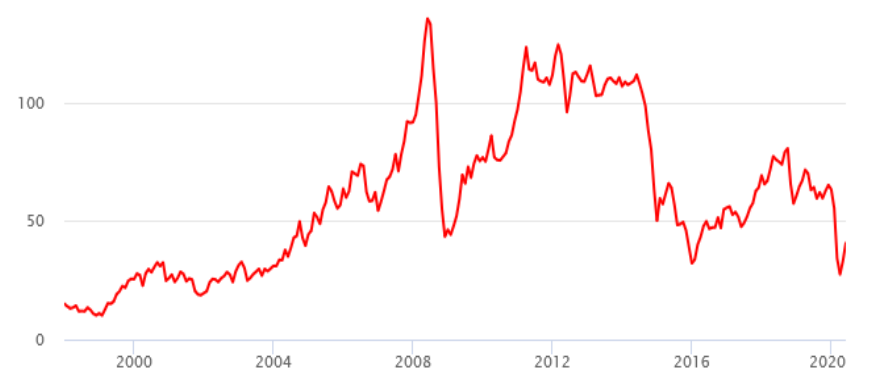

Fig. 2. Dynamics of average annual oil prices of Urals and Brent grades in 2009-2018, dollars per barrel (according to OPEC, Ministry of Economic Development of Russia)

In 2017, thanks to the Agreement on the limitation of oil production between OPEC countries and 11 countries that joined them, stocks and a surplus of raw materials on the market decreased, which, combined with an increase in demand for hydrocarbons, created the conditions for price recovery. As a result, in the indicated year for the Brent brand they grew by $24 \%$ compared to the previous year - up to 54.2 dollars per barrel.

Throughout 2018, oil shortages persisted and supported price increases, which only slowed in the fourth quarter [29-32]. However, this did not prevent the average annual price from increasing by almost a third - up to 69.8 dollars per barrel. for the brand Brent. Options for optimizing innovation management in the supply chains of Russian oil and oil products taking into account the regional structure are presented in Fig. 3, 4. 
International Journal of Engineering Research and Technology. ISSN 0974-3154, Volume 13, Number 11 (2020), pp. 3479-3484

(C) International Research Publication House. https://dx.doi.org/10.37624/IJERT/13.11.2020.3479-3484

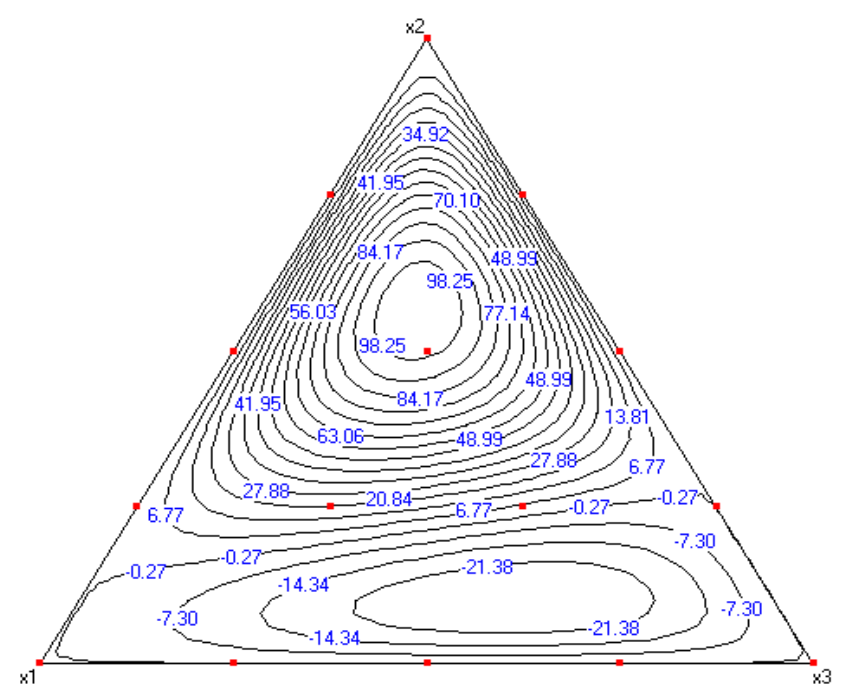

Fig. 3. Optimization scheme of innovation management in the supply chains of Russian oil, taking into account the regional structure

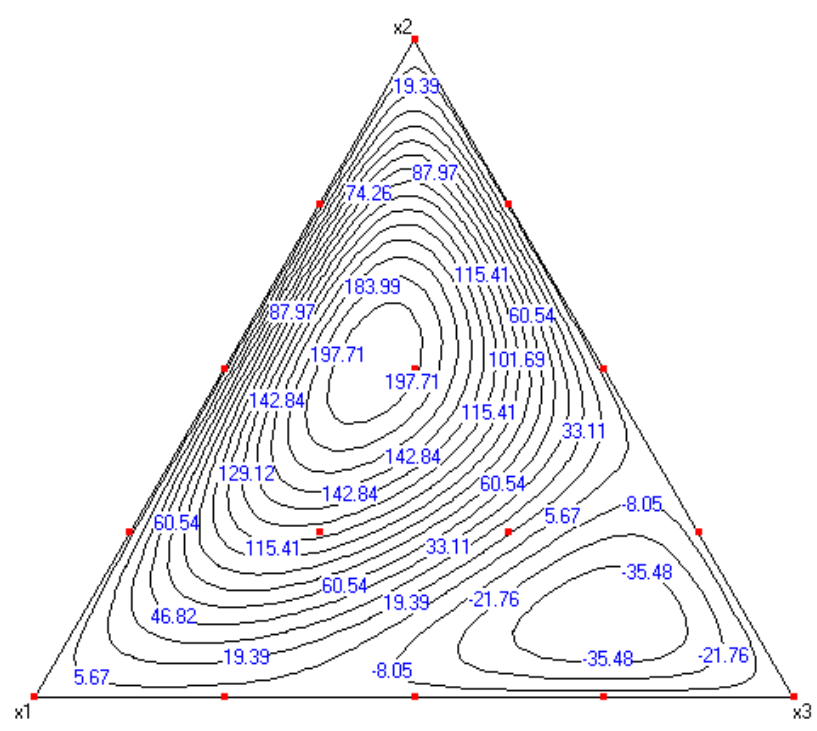

Fig. 4. Optimization scheme for innovation management in the supply chains of Russian petroleum products, taking into account the regional structure

Based on the author's approach of using the simplex optimization method, it is clear that innovation management in the supply chains of Russian oil, taking into account the regional structure, can demonstrate the highest economic efficiency up to 98 billion rubles. in the form of export duties with the ratio of the main oil and gas provinces (Volga-Ural (x1), West-Siberian (x2) and Timan-Pechersk (x3) in the region of 20\%: $65 \%: 15 \%$. The economic efficiency of the presented innovation management method in the supply chains of Russian oil products reaches 197 billion rubles. from the oil of the same regions (Volga Federal District (x1): Ural Federal District (x2) and North-West Federal District (x3)) is somewhat shifted to the region about 35\%: 55\%: 10\%.

\section{ACKNOWLEDGEMENTS}

The work is performed according to the Russian Government Program of Competitive Growth of Kazan Federal University.

The article was prepared based on the results of research conducted within the framework of the state task under the leadership of the Federal Agency of Scientific Organizations of Russia, with the registration number: AAAA-A18118031390148-1.

\section{REFERENCES}

[1] Aimer N. The role of oil price fluctuations on the USD/EUR exchange rate: an ARDL bounds testing approach to cointegration. EUR Exchange Rate: An ARDL Bounds Testing Approach to Cointegration (October 11, 2017). 2017 Oct 11.

[2] Barbier EB. The Role of Natural Resources in Economic Development. Australian Economic Papers. 2003:253-272. doi: 10.1111/1467-8454.00198.

[3] Beilin IL. Economic optimization in chemical enterprises. International Journal of Economic Perspectives. 2017;11(4):670-7.

[4] Kauffman S, Pathak SD, Sen PK, Choi TY. Jury rigging and supply network design: Evolutionary "Tinkering" in the presence of unknown-unknowns. Journal of Supply Chain Management. 2018 Jan;54(1):51-63.

[5] Sriyakul T, Umam R, Jermsittiparsert K. Internal Supply Chain Integration and Operational Performance of Indonesian Fashion Industry Firms: A Supplier to Buyer Appro ach. Humanities and Social Sciences Reviews. 2019;7(2):479-486.

[6] Heil S, Bornemann T. Creating shareholder value via collaborative innovation: the role of industry and resource alignment in knowledge exploration. R\&D Management. 2018 Sep;48(4):394-409.

[7] Beilin I, Homenko V, Aleeva D. Digital modeling of economic processes and supply chain management in the formation of cooperative relations in the petrochemical cluster of the region. SCOPUS20513771-2019-8-4SID85071558090. 2019 Jan 1.

[8] Beilin I, Homenko V, Aleeva D. The development of the school of spatial analysis of W. Isard on the basis of economic and supply chain management models of the petrochemical and chemical production cluster. International Journal of Supply Chain Management. 2019;8(4): 544 - 549.

[9] Vatn A. Institutions and Environment. Cheltenham. UK: Edward Elgar, 2005;482.

[10] Yakupova NM, Levachkova SJ, Kadochnikova EI, Beilin IL. Measurement of cost factors: Evidence from trading companies. International Journal of Economic Perspectives. 2017;11(4):794-802.

[11] Leamer EE. Specification problems in econometrics. InEconometrics 1990 (pp. 238-245). Palgrave Macmillan, London. 
International Journal of Engineering Research and Technology. ISSN 0974-3154, Volume 13, Number 11 (2020), pp. 3479-3484

(C) International Research Publication House. https://dx.doi.org/10.37624/IJERT/13.11.2020.3479-3484

[12] Zhong Y, Zhao Y. The optimal model of oilfield development investment based on Data Envelopment Analysis. Petroleum. 2016;2(3):307-312.

[13] Beilin I, Khomenko V, Kalenskaya N. Improving the management of the industrial development of the region in the context of the integration of enterprises of petrochemical complex. Journal of Advanced Research in Dynamical and Control Systems. 2019;11:1904 1908.

[14] Beilin IL, Khomenko VV, Kalenskaya NV. Institutional aspects of the cluster development of the regional economic system. Humanities \& Social Sciences Reviews. 2019 Nov 19;7(6):192-6.

[15] Jafari Y. Malmquist Productivity Index for Multi Time Periods. International Journal of Data Envelopment Analysis, 2014;2(1): 315-322.

[16] Beilin IL, Khomenko VV, Kalenskaya NV. The Stability of the Regional Economic System Based on the Innovative Development of the Petrochemical Cluster. Academic Journal of Interdisciplinary Studies. 2019;8(4):140-145.

[17] Cravo TA, Becker B, Gourlay A. Regional Growth and SMEs in Brazil: A Spatial Panel Approach. Regional Studies, 2015;49(12):1995-2016. DOI: 10.1080/00343404.2014.890704.

[18] Beilin IL, Khomenko VV, Kalenskaya NV, Solntseva AA. Analysis of the functioning of the regional oil and gas chemical complex and the formation of the region's resource potential. The Journal of Social Sciences Research. 2018;5:245-249.

[19] Beilin IL, Khomenko VV, Kalenskaya NV, Solntseva AA. The significance of the resource intensity of the regional economy the development of the oil and gas chemical complex. The Journal of Social Sciences Research. 2018;5:328-332.

[20] Vagizova V, Homenko V, Akhmetova G. The Volga region banking and real sectors interaction cluster initiatives. Investment Management and Financial Innovations. 2014;11(4):134-141.

[21] Partridge M, Rickman D. Computable General Equilibrium (CGE) Modelling for Regional Economic Development Analysis. Regional Studies. 2010;44(10):1311-1328.
[22] Corrado L, Fingleton B. Where is the economics in spatial econometrics?. Journal of Regional Science, 2012;52(2): 210-239.

[23] Pechenegina TA. Formation of the economic clusters as the impulse of economic growth. International Journal of Applied Business and Economic. Research, 2016;14(15):11025-11032.

[24] Chen X, DemianPouzo, Sieve Wald and QLR inferences on semi/nonparametric conditional moment models. Econometrica, 2015;83:1013-1079.

[25] Sachs JD. Institutions Matter, but Not for Everything: The Role of Geography and Resource Endowments in Development Shouldn't be Underestimated. Finance and Development, 2003;2:38-41.

[26] Bewley T. General Equilibrium, Overlapping Generations Models, and Optimal Growth Theory. Cambridge and London: Harvard University Press, 2007;602.

[27] Barbier EB. Natural Resources and Economic Development. Cambridge University Press, 2005;410.

[28] Sharma M. Economic Growth Potentials and Race/Ethnicity in Tennessee: Diversity and Economy. International Journal of Applied Geospatial Research, 2018; 9(2):33-54. DOI: 10.4018/IJAGR.2018040103.

[29] Perepelitsa DG, Zhdanova OA. Peculiarities of investment decision-making in the oil and gas industry aimed to ensure sustainable growth of the Russian economy. International Journal of Energy Economics and Policy. 2017;7(1):216-223.

[30] Kloyer M, Helm R, Aust C. Determinants of moral hazard in research and development supply relations: Empirical results beyond the agency-theory explanation. Managerial and Decision Economics. 2019 Jan;40(1):6478 .

[31] Flynn BB, Koufteros X, Lu G. On theory in supply chain uncertainty and its implications for supply chain integration. Journal of Supply Chain Management. 2016 Jul;52(3):3-27.

[32] Panico C. Strategic interaction in alliances. Strategic Management Journal. 2017 Aug;38(8):1646-67. 